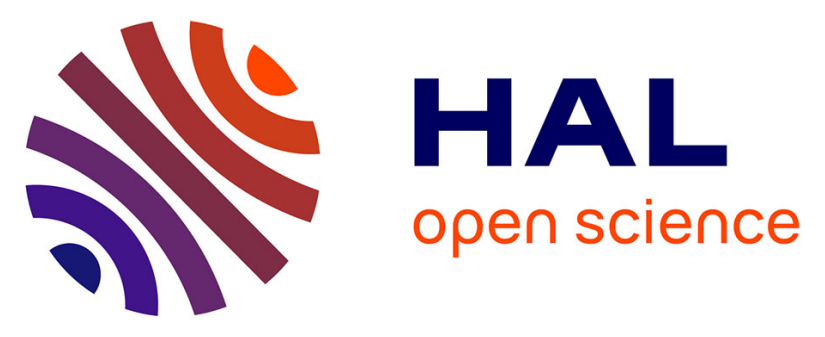

\title{
Palladium supported on magnesium hydroxyl fluoride: an effective acid catalyst for the hydrogenation of imines and N-heterocycles
}

Reshma Kokane, Yann Corre, Erhard Kemnitz, Mohan K Dongare, Francine Agbossou-Niedercorn, Christophe Michon, Shubhangi B Umbarkar

\section{- To cite this version:}

Reshma Kokane, Yann Corre, Erhard Kemnitz, Mohan K Dongare, Francine Agbossou-Niedercorn, et al.. Palladium supported on magnesium hydroxyl fluoride: an effective acid catalyst for the hydrogenation of imines and N-heterocycles. New Journal of Chemistry, 2021, 45 (41), pp.19572-19583. 10.1039/d1nj03760a . hal-03410371

\section{HAL Id: hal-03410371 \\ https://hal.science/hal-03410371}

Submitted on 31 Oct 2021

HAL is a multi-disciplinary open access archive for the deposit and dissemination of scientific research documents, whether they are published or not. The documents may come from teaching and research institutions in France or abroad, or from public or private research centers.
L'archive ouverte pluridisciplinaire HAL, est destinée au dépôt et à la diffusion de documents scientifiques de niveau recherche, publiés ou non, émanant des établissements d'enseignement et de recherche français ou étrangers, des laboratoires publics ou privés. 


\title{
Palladium supported on magnesium hydroxyl fluoride: an effective acid catalyst for the hydrogenation of imines and $N$-heterocycles
}

\author{
Reshma Kokane, ${ }^{\mathrm{a}, \mathrm{b}}$ Yann Corre, ${ }^{\mathrm{c}, \mathrm{d}}$ Erhard Kemnitz, ${ }^{\mathrm{e}}$ Mohan K. Dongare, ${ }^{\mathrm{f}}$ Francine \\ Agbossou-Niedercorn, ${ }^{\mathrm{c}, \mathrm{d}}$ Christophe Michon, ${ }^{* \mathrm{c}, \mathrm{d}, \mathrm{g}}$ Shubhangi B. Umbarkar*a,b \\ ${ }^{a}$ Catalysis Division, CSIR-National Chemical Laboratory, \\ Dr. Homi Bhabha Road, Pune - 411008, India \\ ${ }^{b}$ Academy of Scientific and Innovative Research, CSIR, Ghaziabad - 201002, India. \\ ${ }^{c}$ Univ. Lille, CNRS, Centrale Lille Institut, Univ. Artois, UCCS UMR 8181 \\ - Unité de Catalyse et Chimie du Solide, F-59000 Lille, France. \\ ${ }^{d}$ Centrale Lille, Bat C7, Cité Scientifique, CS20048, 59651 Villeneuve d'Ascq Cedex, France \\ ${ }^{e}$ Institute of Chemistry, Humboldt University, Brook-Taylor-Straße 2, 12489 Berlin, Germany \\ ${ }^{f}$ Malati Fine Chemicals Pvt. Ltd., Panchawati, Pune-411008, India \\ ${ }^{g}$ Université de Strasbourg, Université de Haute-Alsace, Ecole Européenne de Chimie, Polymères et \\ Matériaux, CNRS, LIMA, UMR 7042, 25 rue Becquerel, 67087 Strasbourg, France. \\ cmichon@unistra.fr, Tel.: +33(0)368852797 \\ sb.umbarkar@ncl.res.in,Fax: +912025902633,Tel.: +912025902044
}

\begin{abstract}
Palladium catalysts supported on acidic fluorinated magnesium hydroxide $\mathrm{Pd} / \mathrm{MgF}_{2}$ $\mathrm{x}(\mathrm{OH})_{\mathrm{x}}$ were prepared through precipitation or impregnation methods. Applications to the hydrogenation of various aldimines and ketimines resulted in good catalytic activities at mild temperatures using one atmosphere of hydrogen. Quinolines, pyridines and other $\mathrm{N}$ heterocycles were successfully hydrogenated at higher temperature and hydrogen pressure using low palladium loadings and without the use of any acid additive. Such reactivity trend confirmed the positive effect of the Brønsted and Lewis acid sites from the fluorinated magnesium hydroxide support resulting in the effective pre-activation of $N$-heterocycle substrates and therefore in the good catalytic activity of the palladium nanoparticles during the hydrogenations. As demonstrated in the hydrogenation of imines, the catalyst was recycled up to 10 times without either loss of activity or palladium leaching.
\end{abstract}

Keywords: heterogeneous catalysis, palladium, hydrogenation, imines, $N$-heterocycles, acid free conditions.

\section{Introduction}

Hydrogenation is the most important and relevant catalytic method to reduce a broad scope of functional groups for the synthesis of organic compounds of interest from laboratory to industrial scale. ${ }^{1}$ Though highly active and selective hydrogenations are generally obtained under relatively mild conditions in the presence of homogeneous catalysts, ${ }^{2}$ the separation and reuse of such catalysts are difficult and lead to contaminations of the hydrogenated products. ${ }^{2,3}$ As a result, the development of heterogeneous hydrogenation catalysts is crucial and continues to attract research interests. ${ }^{4}$ Metal-catalysed hydrogenation of organic compounds containing at least one $\mathrm{C}=\mathrm{N}$ functionality, for instance imines and $\mathrm{N}$-heterocycles, ${ }^{5,6}$ have found large applications in industry for the synthesis of key precursors, intermediates as well as fine and 
bulk chemicals. ${ }^{7}$ In particular, 1,2,3,4-tetrahydroquinoline (1,2,3,4-THQ) and its derivatives are part of an important class of compound widely found in the production of fine chemicals, pharmaceuticals, agrochemicals and petrochemicals. ${ }^{8}$ However, by comparison to imines, the hydrogenation of quinolines and other $N$-heteroarenes require higher pressure and temperature conditions due to the high stability of their aromatic rings. In addition, the hydrogenation of $\mathrm{N}$ heterocycles suffers from catalyst deactivation caused by poisoning through the strong interaction between the catalyst active sites and the nitrogen atom of either substrates or the resulting reduced products.

From an industrial perspective, ${ }^{1,9}$ the development of effective and selective heterogeneous catalysts for hydrogenation requires to focus on important parameters like reaction rates, chemo- and regioselectivity, functional group tolerance, stability of the catalysts without metal leaching or nitrogen compounds deactivation, mild reaction conditions, simple procedures and recyclings. During the past decade, several heterogeneous transition metal-based catalysts have been developed in order to overcome catalyst deactivation along the hydrogenation of imines and $N$-heterocycles. Catalysts based on rhodium, ${ }^{10}$ platinum $^{11}$ as well as on ruthenium ${ }^{12}$ or palladium ${ }^{13}$ and recently on cobalt ${ }^{14}$ were immobilized on different solid materials but, overall, several challenges remain to be met in order to develop highly active, selective, stable and reusable catalysts for the hydrogenation of imines and $N$-heterocycles.

In heterogeneous catalysis, the nature of the solid-support materials plays a critical role in the catalytic reactions providing access to different surface, mechanical, texture, thermal, electronic, redox and acid-base properties. ${ }^{15}$ While metal-support interactions govern the dispersion and electronic structures of metal species, substrate-support interactions offer the opportunity to assist and direct the catalyst reactivity. In the context of the hydrogenation of imines and $N$-heterocycles, the use of solid support materials which exhibit Brønsted and Lewis acid properties is attractive in order to activate the nitrogen substrates and therefore facilitate the catalytic hydrogenation. In addition, the use of catalysts supported on acidic materials may allow catalytic hydrogenations of pyridines without the use of an acid additive which is often required for pre-activation of $N$-heterocycles. ${ }^{16}$

Along our long term research effort to develop catalysts for reduction reactions, ${ }^{17,18}$ we have reported new palladium catalysts supported on fluorinated magnesium hydroxide which have displayed interesting acidic properties. We have demonstrated the hydrogenation of olefins to alkanes $^{18 \mathrm{a}}$ and the reduction of nitroarenes to anilines ${ }^{18 \mathrm{~b}}$ are effectively and selectively catalysed by these new palladium solid-support materials. Herein, we report such acidic catalysts can be prepared by two different procedures and are versatile to hydrogenate imines, quinolines and several other challenging $N$-heterocycles in mild conditions and without any acid additive.

\section{Results and Discussions}

\section{Catalyst preparation and characterization}

The catalysts $\left(\mathrm{Pd}-\mathrm{MgF}_{2}-\mathrm{x}(\mathrm{OH})_{\mathrm{x}}\right)$ were prepared following 2 methods: coprecipitation or impregnation. The synthesis by coprecipitation method has been carried out as reported previously following a simple sol-gel procedure. ${ }^{18}$ Hence, the synthesis of the palladium catalyst (1PMF-ppt) supported on fluorinated magnesium hydroxide $\left(\mathrm{MgF}_{2} \mathrm{x}(\mathrm{OH})_{\mathrm{x}}\right)$ started by 
fluorination of magnesium hydroxide in the presence of aqueous $\mathrm{HF}$ followed by palladium impregnation during the slow precipitation of $\mathrm{MgF}_{2-\mathrm{x}}(\mathrm{OH})_{\mathrm{x}}$ initiated by addition of a methanol solution of palladium acetate at $1 \mathrm{wt} \%$ Pd loading. The resulting palladium material exhibited an acidic nature (total acidity: $0.29 \mathrm{mmol} / \mathrm{g} \mathrm{NH}_{3}$ desorbed) relying on Lewis acid sites and a high surface area of $106 \mathrm{~m}^{2} / \mathrm{g}$ with palladium particle sizes in the range of $10-11 \mathrm{~nm}$. Palladium dispersion was determined at $8 \%$ with Pd metal surface area of $0.37 \mathrm{~m}^{2} / \mathrm{g}$.

Regarding the impregnation method, the palladium catalyst (1PMF-imp) supported on magnesium hydroxy fluoride $\left(\mathrm{MgF}_{2}-\mathrm{x}(\mathrm{OH}) \mathrm{x}\right)$ was achieved by preparing first the magnesium hydroxyl fluoride by simple precipitation from magnesium oxide and HF in a methanol/water solvent mixture. Afterwards, the resulting solid was impregnated with palladium acetate diluted in methanol at $1 \mathrm{wt} \%$ Pd loading.

The powder X-ray diffraction patterns of catalysts (1PMF-imp) and (1PMF-ppt) respectively prepared by impregnation and precipitation methods appeared very similar (Figure 1). The diffraction peaks were observed at $2 \theta=27.38(110), 35.28$ (101), 40.48 (111), 43.88 (201), 53.58 (211), 56.28 (220), 60.78, 68.18 (301), 77.48, and 87.48 and were typical of the magnesium fluoride phase. ${ }^{18}$ Due to low loadings, no peaks corresponding to palladium ${ }^{12 \mathrm{c}, \mathrm{d}, \mathrm{f}}$ were observed in both catalysts.

The BET analysis of the catalyst (1PMF-imp) prepared by impregnation revealed a surface area of $75 \mathrm{~m}^{2} / \mathrm{g}$ and a pore size of $3.1 \mathrm{~nm}$ (Figure 2). In addition, the chemisorptions study revealed a $13.1 \%$ metal dispersion (Table 1). By comparison, the surface area and pore size of catalyst (1PMF-ppt) were higher with $106 \mathrm{~m}^{2} / \mathrm{g}$ and $4.8 \mathrm{~nm}$, the smaller surface area of catalyst (1PMF-imp) prepared by impregnation method being probably due to the blockage of the support pores by palladium particles. However, it was worth to note the chemisorption study revealed an improved metal dispersion for catalyst (1PMF-imp) (13.1\%) compared to catalyst (1PMF-ppt) (8\%) (Table 1).

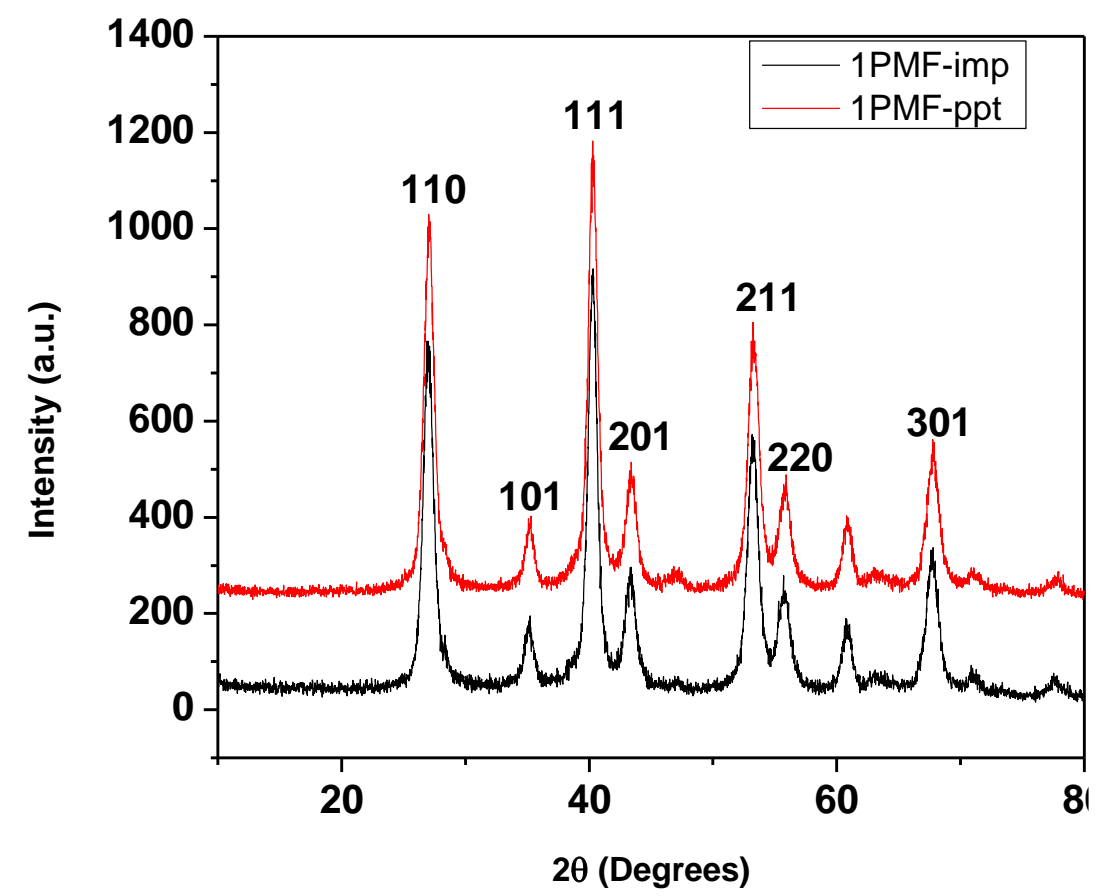

Figure 1. Powder XRD patterns of 1PMF-ppt (red) and 1PMF-imp (black) 

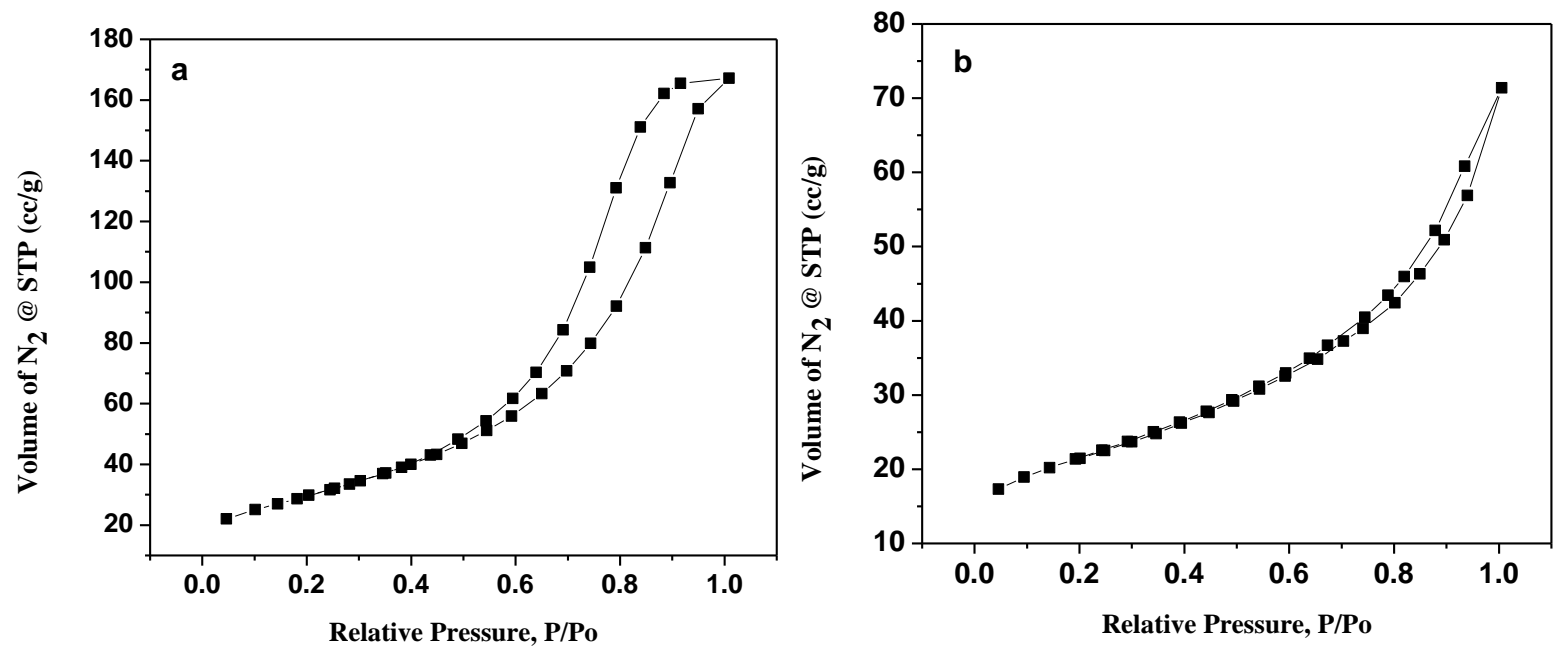

Figure 2. BET surface area analysis of (a) 1PMF-ppt (b) 1PMF-imp

Table 1. Surface characterization of catalysts

\begin{tabular}{ccccc}
\hline Catalyst & $\begin{array}{c}\text { Surface area } \\
\left(\mathbf{m}^{2} \mathbf{g}\right)\end{array}$ & $\begin{array}{c}\text { Pore size } \\
(\mathbf{n m})\end{array}$ & $\begin{array}{c}\text { Pore volume } \\
(\mathbf{c c} / \mathbf{g})\end{array}$ & $\begin{array}{c}\text { Metal dispersion } \\
(\mathbf{\%})^{\boldsymbol{a}}\end{array}$ \\
\hline 1PMF-ppt & 106 & 4.8 & 0.25 & 8.0 \\
1PMF-imp & 75 & 3.1 & 0.11 & 13.1 \\
\hline${ }^{a}$ From CO chemisorptions study & & &
\end{tabular}

Thus, the catalyst synthesis by impregnation method resulted in a successful increase of the availability of palladium on the surface. ${ }^{18,19}$

Analyses by ammonia temperature programmed desorption $\left(\mathrm{NH}_{3}\right.$ TPD) were performed to determine the total acidity and acidic strength of both catalysts and similar acidities were observed (Figure 3). The amount of ammonia desorbed from the surface was $0.80 \mathrm{mmol} / \mathrm{g}$ at $362{ }^{\circ} \mathrm{C}$ and confirmed the presence of moderate acidic sites in case of catalyst (1PMF-imp). Regarding catalyst (1PMF-ppt) synthesized by precipitation method, the amount of ammonia desorbed from surface was slightly lower with $0.76 \mathrm{mmol} / \mathrm{g}$ at $350{ }^{\circ} \mathrm{C}$.

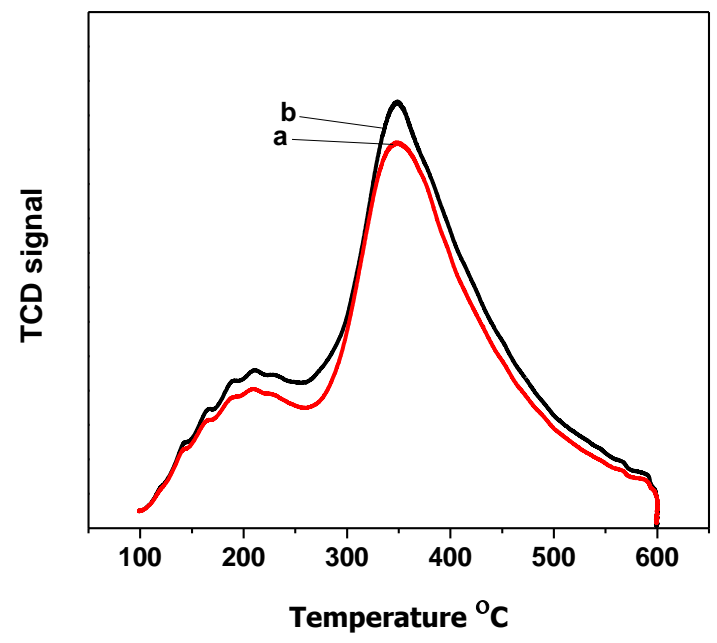

Figure 3. $\mathrm{NH}_{3}$ TPD profile of (a) 1PMF-ppt; (b) 1PMF-imp 


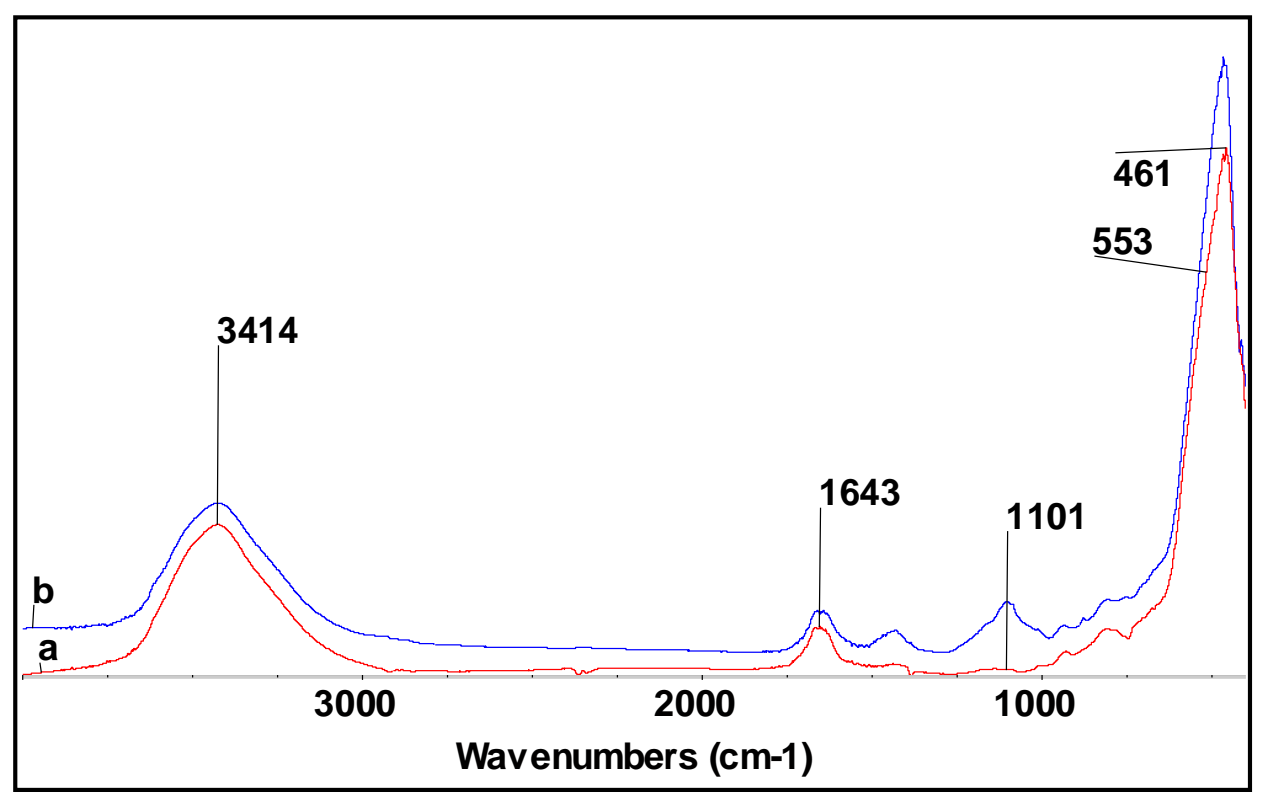

Figure 4. FTIR analysis of (a) 1PMF-ppt, (b) 1PMF-imp

FTIR spectra of the two catalysts prepared by impregnation and precipitation methods showed similar features (Figure 4). The vibration bands at $553 \mathrm{~cm}^{-1}$ and $461 \mathrm{~cm}^{-1}$ confirmed the presence of $\mathrm{Mg}-\mathrm{O}$ and $\mathrm{Mg}-\mathrm{F}$ species. ${ }^{18 \mathrm{a}}$ The broad bands at $3414 \mathrm{~cm}^{-1}$ were most likely resulting from the adsorbed water molecules and the vibrations observed at $1643 \mathrm{~cm}^{-1}$ may correspond to $\mathrm{O}-\mathrm{H}$ bending vibrations due to the presence of surface $\mathrm{O}-\mathrm{H}$ as a result of adsorbed water or O-H groups on surface. The observed bands in the range of $1500-1400 \mathrm{~cm}^{-1}$ and 1050 $1150 \mathrm{~cm}^{-1}$ were assigned respectively to the $\mathrm{CH}_{3}$ deformations and $\mathrm{C}-\mathrm{O}$ stretching vibrations from the acetate anions of the palladium salt used for the catalyst synthesis, suggesting the cationic nature of the supported palladium and therefore its oxidation state (II). However, under hydrogen, a partial reduction of catalyst 1 PMF-ppt particles from palladium (II) to palladium (0) was previously observed through XPS and UV-Vis spectroscopy. ${ }^{18 a, b}$

SEM and EDX analyses of both catalysts were carried out and no define morphology was observed (Figures 5 and 6). EDX analysis showed a higher percentage of palladium in case of impregnated catalyst by comparison to the catalyst prepared by precipitation method (Table 2). This was in good agreement with data obtained from BET and chemisorption studies and indicated a higher amount of loaded palladium was available on the surface while using catalyst (1 PMF-imp).

TEM analysis allowed to investigate the palladium particle size of the catalyst (1 PMF-imp) prepared by impregnation method (Figure 5). The palladium and magnesium fluoride particles were characterized by their typical d spacing values. The micrograph (Figure $5 \mathrm{~B}$ ) showed the presence of palladium nanoparticles with d spacing of $0.22 \mathrm{~nm}$ which corresponded to (111) plane of palladium. The presence of (110) plane in magnesium fluoride particles was identified by the $\mathrm{d}$ spacing value of $0.32 \mathrm{~nm}$, which was in good agreement with the XRD analysis. The average particle size was found to be $7-8 \mathrm{~nm}$ for catalyst (1 PMF-imp) prepared by impregnation method although the particle size distribution from 5 to $16 \mathrm{~nm}$ was broad. 


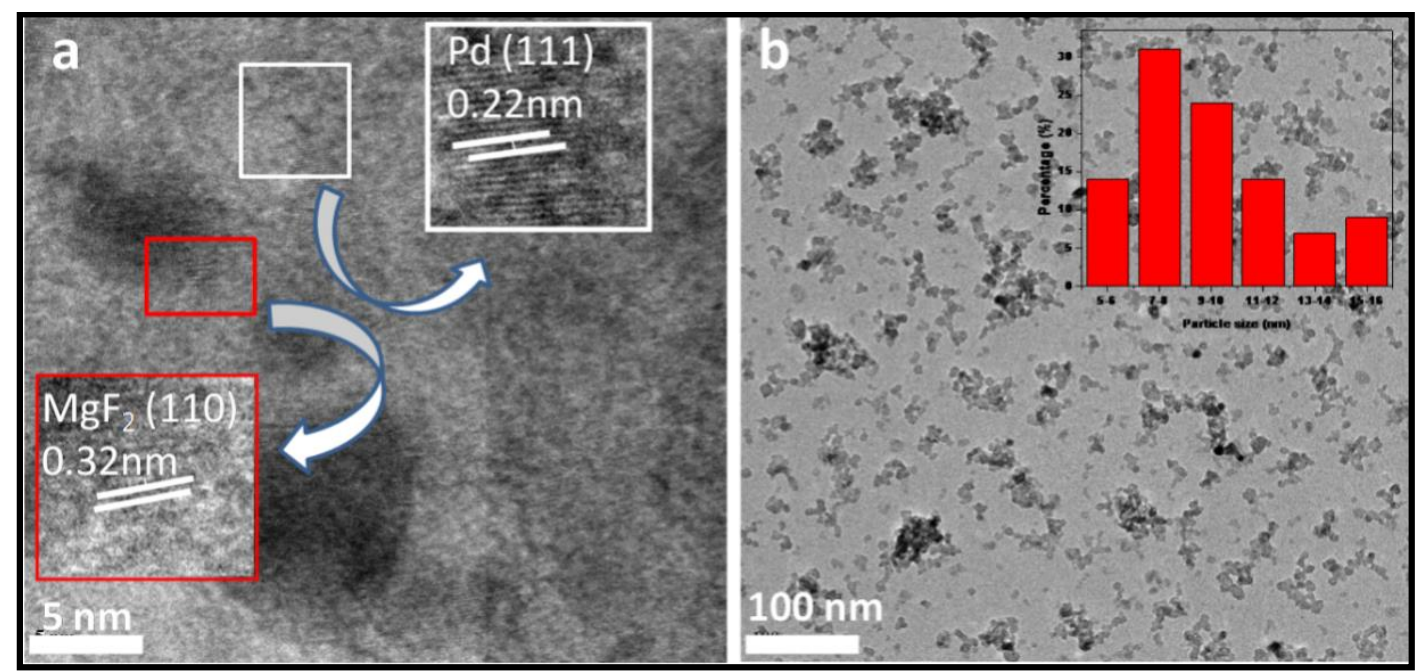

Figure 5. TEM images of 1PMF-imp

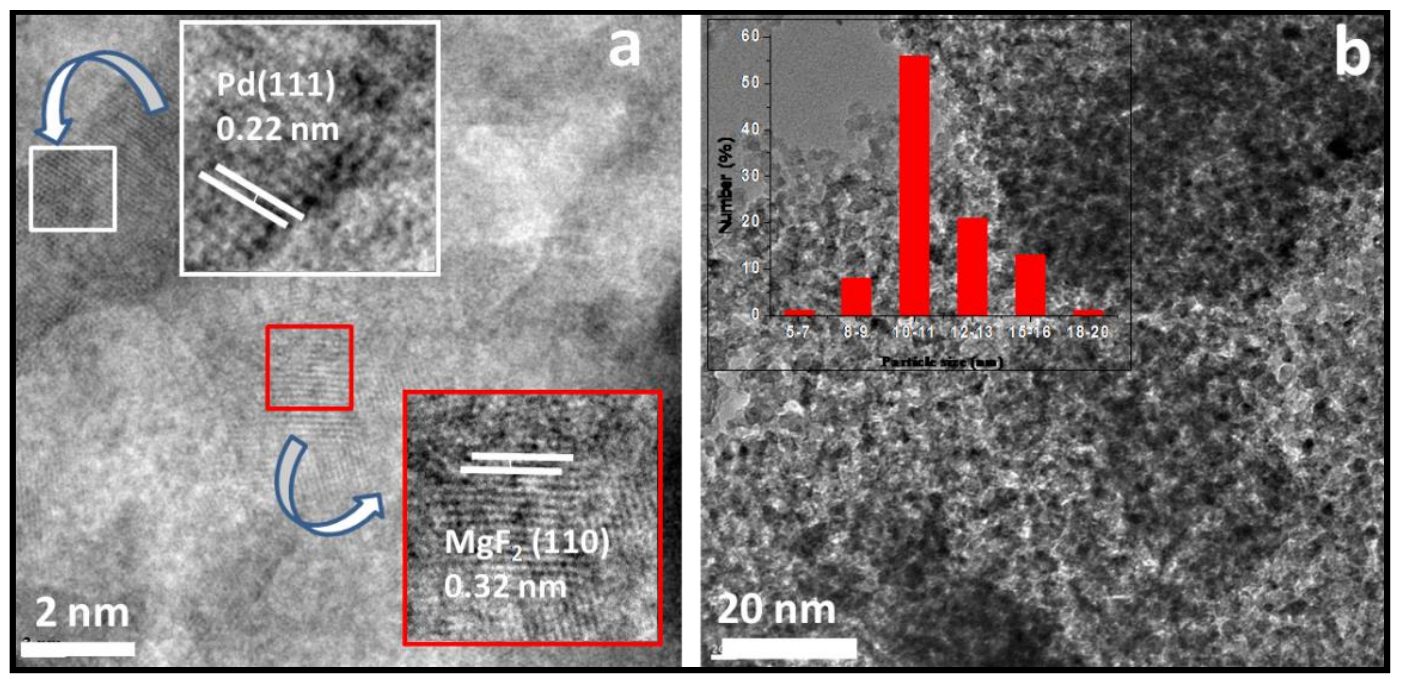

Figure 6. TEM images of 1PMF-ppt

Table 2. EDX analysis of catalysts

\begin{tabular}{cccccc}
\hline \multirow{2}{*}{ Entry } & \multirow{2}{*}{ Catalyst } & \multicolumn{4}{c}{ Elemental Composition (\%) } \\
\cline { 3 - 6 } & & Pd & Mg & F & O \\
\hline 1 & 1PMF-ppt & 0.78 & 34.17 & 43.46 & 21.59 \\
2 & 1PMF-imp & 0.98 & 34.48 & 49.30 & 15.24 \\
\hline
\end{tabular}

The TEM analysis of the catalyst (1PMF-ppt) was next performed for comparison. The particle size distribution was broad spreading from 5 to $20 \mathrm{~nm}$ and the average palladium particle size was found in the range of 10-11 nm which was slightly higher compared to catalyst (1PMFimp) (Figure 6). On the whole, the extensive characterizations of the synthesized catalysts revealed the catalyst (1PMF-imp) prepared by impregnation method had a higher metal dispersion and smaller palladium particles than the catalyst (1PMF-ppt) prepared by precipitation. 
Table 3. Catalyst loading and solvent effect on the hydrogenation of imine 1a using catalysts (1PMFppt) and (1PMF-imp).

\begin{tabular}{|c|c|c|c|c|c|c|}
\hline & & $\widehat{1}_{1 \mathrm{~N}}{ }^{-P h}$ & 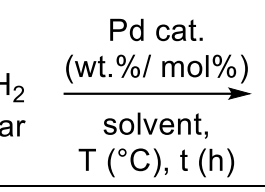 & $\widehat{2 a}_{\mathrm{H}}$ & & \\
\hline Entry & $\begin{array}{c}\text { Catalyst } \\
\text { (loading wt\%) }\end{array}$ & $\begin{array}{l}\text { Pd loading } \\
(\mathbf{m o l} \%)^{\mathrm{a}}\end{array}$ & Solvent & $\underset{\text { (h) }}{\text { Time }}$ & $\begin{array}{c}\mathbf{T} \\
\left({ }^{\circ} \mathbf{C}\right)\end{array}$ & $\begin{array}{l}\text { Yield } \\
(\%)^{b}\end{array}$ \\
\hline $1^{\mathrm{c}}$ & 1PMF-ppt (5) & 0.013 & methanol & 2 & 27 & 12 \\
\hline $2^{c}$ & 1PMF-ppt (5) & 0.013 & methanol & 5 & 27 & 99 \\
\hline $3^{\mathrm{c}}$ & 1PMF-ppt (10) & 0.027 & methanol & 2 & 27 & 58 \\
\hline $4^{\mathrm{c}}$ & 1PMF-ppt (10) & 0.027 & methanol & 3 & 27 & 99 \\
\hline $5^{c}$ & 1PMF-ppt (15) & 0.040 & methanol & 2 & 27 & 99 \\
\hline $6^{c}$ & 1PMF-ppt (10) & 0.027 & methanol & 2 & 40 & 80 \\
\hline $7^{\mathrm{c}}$ & 1PMF-ppt (10) & 0.027 & methanol & 2 & 60 & 99 \\
\hline $8^{c}$ & 1PMF-ppt (10) & 0.027 & methanol & 1 & 60 & 58 \\
\hline $9^{c}$ & 1PMF-ppt (10) & 0.027 & methanol & 0.5 & 60 & 22 \\
\hline $10^{\mathrm{d}}$ & 1PMF-imp (10) & 0.032 & methanol & 1 & 60 & 99 \\
\hline $11^{\mathrm{d}}$ & 1PMF-imp (10) & 0.032 & methanol & 0.5 & 60 & 40 \\
\hline $12^{\mathrm{c}}$ & 1PMF-ppt (10) & 0.027 & ethanol & 2 & 27 & 40 \\
\hline $13^{\mathrm{c}}$ & 1PMF-ppt (10) & 0.027 & toluene & 2 & 27 & 15 \\
\hline $14^{\mathrm{c}}$ & 1PMF-ppt (10) & 0.027 & $n$-hexane & 2 & 27 & 12 \\
\hline $15^{\mathrm{c}}$ & 1PMF-ppt (10) & 0.027 & dichloroethane & 2 & 27 & 18 \\
\hline
\end{tabular}

\section{Catalytic hydrogenations}

The first applications in catalysis focused on the hydrogenation of $N$-benzylideneaniline 1a as a benchmark reaction in order to optimize the experimental conditions (Table 3). Hydrogenations of imine 1a were performed in the presence of catalysts (1PMF-ppt) and (1PMF-imp) under an atmospheric pressure of $\mathrm{H}_{2}$. In methanol, a complete hydrogenation of 1 a into $N$-benzylaniline 2a was obtained within 5 hours by using $5 \mathrm{wt} \%$ / $0.013 \mathrm{~mol} \%$ of (1PMF-ppt) catalyst at $27^{\circ} \mathrm{C}$ (entries 1 and 2). The (1PMF-ppt) catalyst loading was increased to 10 and $15 \mathrm{wt} \%$ (that is to say to 0.027 to $0.04 \mathrm{~mol} \%$ palladium as determined by $\mathrm{H}_{2}$ chemisorption) allowing quantitative hydrogenations within respectively 3 and 2 hours (entries 3-5). With a (1PMF-ppt) catalyst loading of $10 \mathrm{wt} . \%$ / 0.027 mol\% palladium, an increase of the temperature to $60{ }^{\circ} \mathrm{C}$ afforded $N$-benzylaniline 2a quantitatively in 2 hours of reaction (entries 6-7), shorter reaction times resulting in lower yields (entries 8-9). By comparison, the (1PMF-imp) catalyst was more active hydrogenating quantitatively $N$-benzylideneaniline $\mathbf{1 a}$ into $N$-benzylaniline $2 \mathbf{a}$ within a single hour at $60^{\circ} \mathrm{C}$ in methanol (entry 10). Considering the 
average yield obtained in 0.5 hour (entry 11), catalyst 1PMF-imp was rather similar to catalyst 1PMF-ppt requiring an activation period to be fully active. Indeed, because this catalyst contained supported palladium (II) particles as highlighted by FTIR analysis (Figure 4), a reduction into palladium (0) was likely to proceed as already observed for catalyst (1PMFppt). ${ }^{18 a, b}$ By screening other solvents (entries 12-15), we noticed the efficiency of the catalysed hydrogenation decreased according the following order: methanol > ethanol > dichloroethane $>$ toluene $>n$-hexane. This activity trend is in correlation with the polarity and/or protic nature of the solvents which decreases following the same order. ${ }^{20}$

Table 4. Hydrogenation of aldimines 1a-g using catalyst (1PMF-ppt).

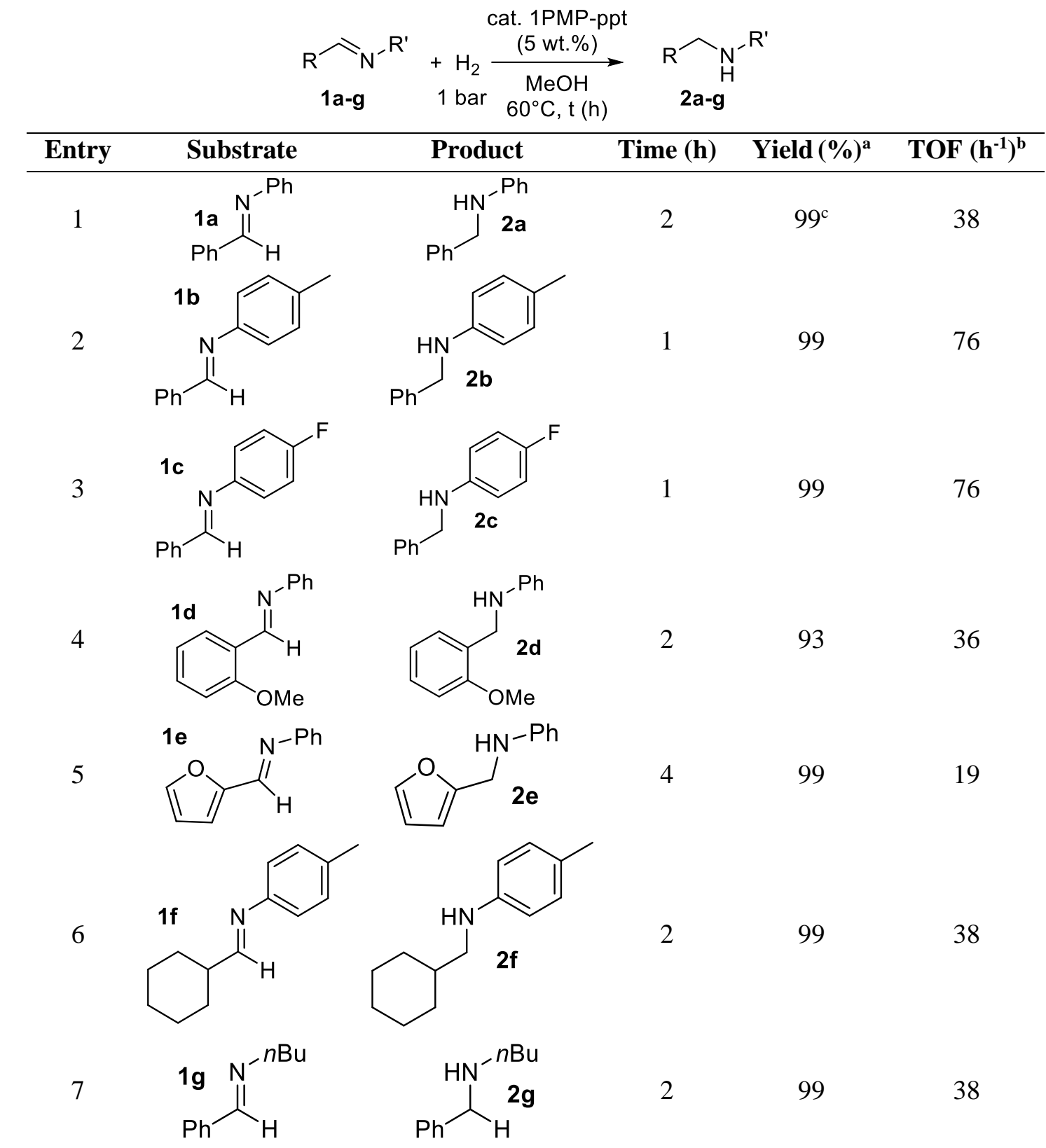

${ }^{a} \mathrm{GC}$ yields. Substrate (0.055 mmol / 0.1g of 1), catalyst (1PMF-ppt) (0.005 g, 5 wt.\%, $0.013 \mathrm{~mol} \%$ of Pd), MeOH $5.0 \mathrm{~mL}$, $\mathrm{H}_{2} 1 \mathrm{bar}, 60^{\circ} \mathrm{C}$. ${ }^{\mathrm{b}}$ Turnover frequency $=$ mol of product $/ \mathrm{mol}$ of catalyst/hour. ${ }^{\mathrm{c}}$ Same result with catalyst $1 \mathrm{PMP}-\mathrm{imp}(0.005 \mathrm{~g}$, 5 wt. $\%, 0.016 \mathrm{~mol} \%$ of Pd), MeOH $5.0 \mathrm{~mL}, \mathrm{H}_{2} 1$ bar, $60{ }^{\circ} \mathrm{C}$ for $1 \mathrm{~h}$, TOF $62 \mathrm{~h}^{-1}$. 
Table 5. Hydrogenation of ketimines 3a-i using catalyst (1PMF-ppt).

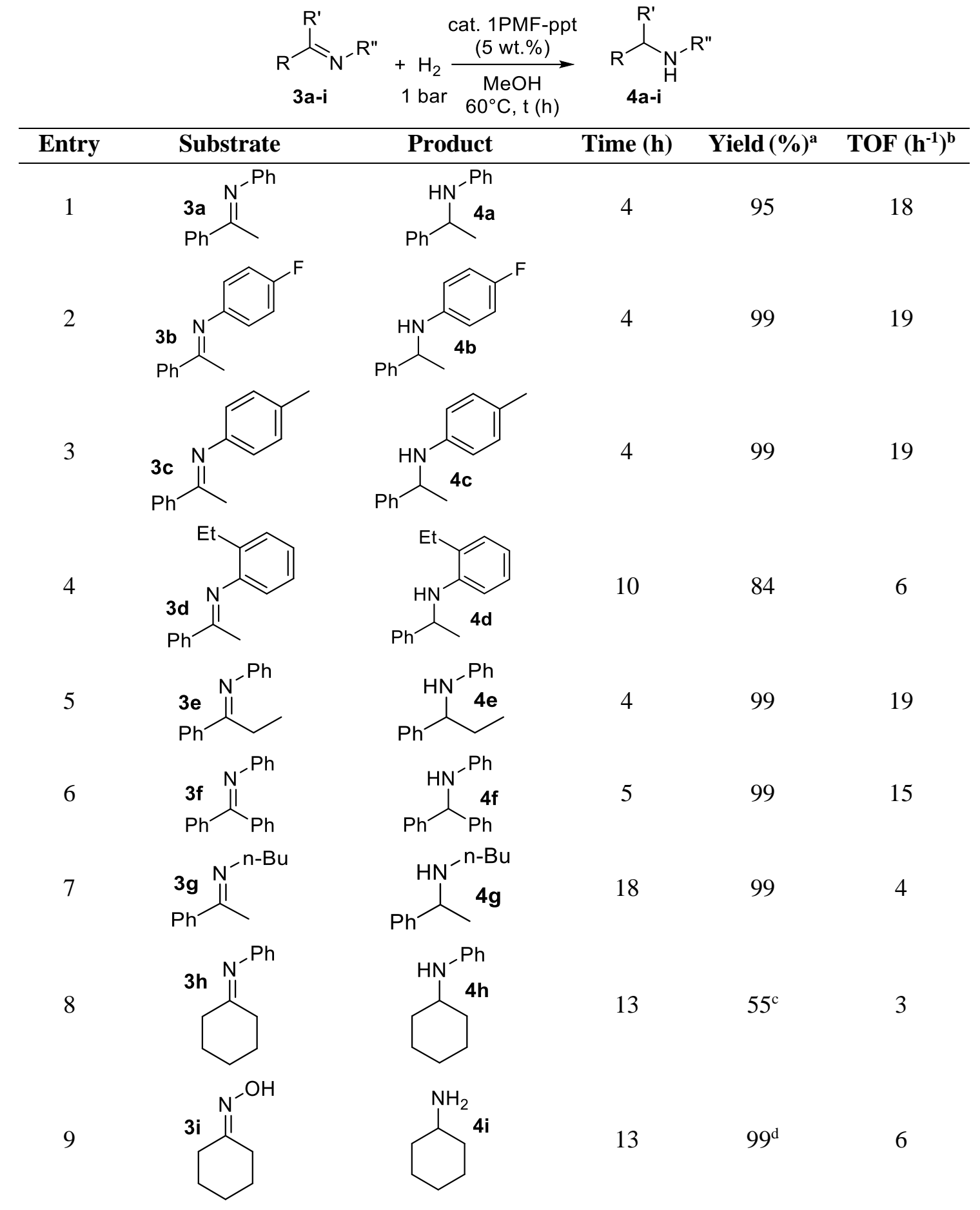

${ }^{\mathrm{a}} \mathrm{GC}$ yields. Substrate (0.055 mmol, $0.1 \mathrm{~g}$ aver.), catalyst (1PMF-ppt) (0.005 g, 5 wt.\%, $0.013 \mathrm{~mol} \%$ of Pd), MeOH (5.0 $\mathrm{mL}), \mathrm{H}_{2}$ (1bar), $60{ }^{\circ} \mathrm{C} .{ }^{\mathrm{b}}$ Turnover frequency $=$ mol of product $/ \mathrm{mol}$ of catalyst/hour. ${ }^{\mathrm{c}} 10 \mathrm{bar} \mathrm{H}_{2}, 91 \%$ yield in $48 \mathrm{~h} .{ }^{\mathrm{d}} 10 \mathrm{bar}$ $\mathrm{H}_{2}$ and $25^{\circ} \mathrm{C}$.

Moreover, protic solvents are commonly used in hydrogenation reactions because they promote rapid reaction by activating the substrate through coordination like $\mathrm{H}$-bonding. ${ }^{21}$

Hydrogenation of a series of aldimines was then investigated in methanol at $60{ }^{\circ} \mathrm{C}$ using catalyst (1PMF-ppt) at a loading of $10 \mathrm{wt} . \%$ / $0.027 \mathrm{~mol} \%$ palladium (Table 4). All reactions proceeded quantitatively and selectively within few hours and without any hydrolysis of the 
substrates. By comparison to $\mathbf{1 a}$, imines $\mathbf{1 b}$ and $\mathbf{1 c}$ bearing fluorine or methyl substituents on the $N$-aryl ring reacted faster affording the amines $\mathbf{2 b}$ and $\mathbf{2 c}$ with almost full conversions in 1 hour (Table 4, entries 1-3). By comparison, aldimine 1d bearing an ortho methoxy substituted aryl reacted slower leading to amine $\mathbf{2 d}$ in a $93 \%$ yield in 2 hours (entry 4 ) and the furan containing imine $1 \mathbf{e}$ even required 4 hours to be completely reduced in $\mathbf{2 e}$ (entry 5). Aldimines 1f and $\mathbf{1 g}$ respectively substituted by a cyclohexyl and a $n$-butyl were also hydrogenated quantitatively in 2 hours (entries 6 and 7). On the whole, turnover frequencies were in the range of 19 to $76 \mathrm{~h}^{-1}$.

By comparison to aldimines, ketimines were also hydrogenated effectively at $60{ }^{\circ} \mathrm{C}$ in good to excellent yields though requiring longer reaction times (Table 5). At the exception of the more sterically hindered substrate $\mathbf{3 d}$ which led to alcohol $\mathbf{4 d}$ in a $84 \%$ yield within 10 hours reaction, ketimines 3a-c and 3e-f bearing two or three aryl substituents were hydrogenated to the corresponding alcohols in almost quantitative yields within few hours (Table 5, entries 1-6). Much slower reactions were observed for alkyl substituted ketimines 3g$\mathbf{h}$ which required longer reaction times and a higher hydrogen pressure (10 bar for $\mathbf{3 h}$ ) in order to proceed well (entries 7,8 ). It was worth to note cyclohexanone oxime $3 \mathbf{i}$ was hydrogenated quantitatively into cyclohexylamine $4 \mathbf{i}$ under similar conditions: 10 bar $\mathrm{H}_{2}, 60{ }^{\circ} \mathrm{C}$ and 13 hours of reaction (entry 9). Overall, turnover frequencies were in the range of 3 to $19 \mathrm{~h}^{-1}$.

We then applied the prepared catalysts to the catalytic hydrogenation of several $\mathrm{N}$ heteroarenes. First, quinolines and then pyridine, pyrazine, acridine, and indoles were examined (Tables 6, 7). By comparison to imines, these aromatic compounds required higher hydrogen pressures $(20 \mathrm{bar})$ and temperatures $\left(90^{\circ} \mathrm{C}\right)$ as well as longer reaction times (24 - 63 h) to react effectively. The hydrogenation of quinoline 5a into 1,2,3,4-tetrahydroquinoline $\mathbf{6 a}$ required $48 \mathrm{~h}$ in order to obtain a $42 \%$ yield by using catalyst (1PMF-ppt) (Table 6, entry 1). It was worth to note the application of catalyst (1PMF-imp) led to an improved yield (60\%) within the same reaction time (entry 2). By comparison, 2-methylquinoline $\mathbf{5 b}$ reacted faster, the hydrogenated product $\mathbf{6 b}$ being obtained in a $90 \%$ yield within $24 \mathrm{~h}$ of reaction using catalyst (1PMF-ppt) (entry 3). The same catalyst allowed the quantitative hydrogenation of 8 hydroxyquinoline $\mathbf{5 c}$ in $48 \mathrm{~h}$ (entry 4) but the reduction of 5-hydroxyquinoline $\mathbf{5 d}$ proved to be harder; the hydrogenated product $\mathbf{6 d}$ was obtained in a $31 \%$ yield within $48 \mathrm{~h}$ using catalyst (1PMF-ppt) and in a 49\% yield after $60 \mathrm{~h}$ of reaction with catalyst (1PMF-imp) (entries 5-6). Though catalyst (1PMF-ppt) was previously shown to avoid hydrodehalogenation ${ }^{11 \mathrm{~b}, 22}$ while reducing $\mathrm{p}$-chloronitrobenzene into $\mathrm{p}$-chloroaniline at room temperature and $1 \mathrm{bar} \mathrm{H}_{2},{ }^{18 \mathrm{~b}}$ the hardest reaction conditions applied for the hydrogenation of 2-chloroquinoline 5e led to dechlorinated product 1,2,3,4-tetrahydroquinoline $6 \mathbf{a}$ in a $99 \%$ yield within 48 hours (entry 7). Similarly, a decarboxylation was observed while using catalyst (1PMF-ppt) for the hydrogenation of quinoline-3-carboxylic acid $\mathbf{5 f}$, 1,2,3,4-tetrahydroquinoline being quantitatively obtained within 48 hours (Entry 8). The combination of the strong reaction conditions and the acidity of catalyst (1PMF-ppt) may explain such a decarboxylation. ${ }^{13 f, 23} \mathrm{By}$ comparison, the hydrogenation of methyl quinoline-2-carboxylate $\mathbf{5 g}$ proceeded chemoselectively in a modest $27 \%$ yield of hydrogenated product $\mathbf{6 g}$ using catalyst (1PMFppt) for $48 \mathrm{~h}$ (entry 9). 
Table 6. Hydrogenation of quinolines 5a-g using catalysts (1PMF-ppt) and (1PMF-imp).

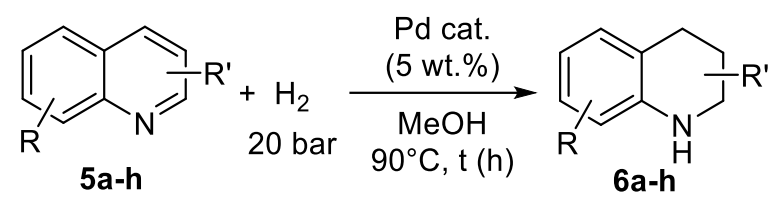

\begin{tabular}{|c|c|c|c|c|c|c|}
\hline Entry & Substrate & Product & Catalyst & $\begin{array}{c}\text { Time } \\
\text { (h) }\end{array}$ & $\begin{array}{l}\text { Yield } \\
(\%)^{\mathrm{a}}\end{array}$ & $\begin{array}{c}\text { TOF }^{\mathbf{b}} \\
\left(\mathbf{h}^{-1}\right)\end{array}$ \\
\hline 1 & & & 1PMF-ppt ${ }^{\mathrm{c}}$ & 48 & 42 & 0.7 \\
\hline 2 & & & 1PMF-imp ${ }^{\mathrm{d}}$ & 48 & 60 & 0.8 \\
\hline 3 & & & 1PMF-ppt ${ }^{\mathrm{c}}$ & 24 & 90 & 2.9 \\
\hline 4 & & & 1PMF-ppt ${ }^{\mathrm{c}}$ & 48 & 99 & 1.6 \\
\hline 5 & & & 1PMF-ppt ${ }^{\mathrm{c}}$ & 48 & 31 & 0.5 \\
\hline 6 & & & 1PMF-imp ${ }^{d}$ & 60 & 49 & 0.5 \\
\hline 7 & & & 1PMF-ppt ${ }^{\mathrm{c}}$ & 48 & 99 & 1.6 \\
\hline 8 & & & 1PMF-ppt ${ }^{\mathrm{c}}$ & 48 & 99 & 1.6 \\
\hline 9 & & & 1PMF-ppt ${ }^{\mathrm{c}}$ & 48 & 27 & 0.4 \\
\hline 10 & & & 1PMF-imp ${ }^{d}$ & 60 & 75 & 0.8 \\
\hline
\end{tabular}

${ }^{\mathrm{a}} \mathrm{GC}$ yields. ${ }^{\mathrm{b}}$ Turnover frequency $=\mathrm{mol}$ of product $/ \mathrm{mol}$ of catalyst $/$ hour. ${ }^{\mathrm{c}}$ Substrate $(0.055 \mathrm{mmol}, 0.1 \mathrm{~g}$ aver. $)$, catalyst (1PMF-ppt) (0.005 g, 5wt.\%, $0.013 \mathrm{~mol} \%$ of Pd), $\mathrm{MeOH}(5.0 \mathrm{~mL}), 20$ bar H2, $90{ }^{\circ} \mathrm{C} .{ }^{\mathrm{d}}$ Substrate $(0.055 \mathrm{mmol}, 0.1 \mathrm{~g}$ aver.), catalyst (1PMF-imp) (0.005 g, 5wt.\%, $0.016 \mathrm{~mol} \%$ of $\mathrm{Pd}), \mathrm{MeOH}(5.0 \mathrm{~mL}), 20 \mathrm{bar}_{2}, 90{ }^{\circ} \mathrm{C}$.

Interestingly, the application of catalyst (1PMF-imp) with a reaction time of $60 \mathrm{~h}$ afforded $\mathbf{6 g}$ in an improved $75 \%$ yield (entry 10). On the whole, turnover frequencies were in the range of 0.4 to $2.9 \mathrm{~h}^{-1}$.

The hydrogenation of several other $N$-heteroarenes was subsequently studied (Table 7). It was worth to note catalyst (1PMF-ppt) allowed the straightforward hydrogenation of pyridine $7 \mathbf{a}$ into piperidine $8 \mathbf{a}$ in a $69 \%$ yield after $48 \mathrm{~h}$ (entry 1). Indeed, at the opposite of most of the 
heterogenous catalysts applied to the hydrogenation of pyridines, catalyst (1PMF-ppt) did not require the addition of an acid additive for pre-activation of the substrate and subsequent hydrogenation. ${ }^{16}$ Under similar conditions, pyrazine $\mathbf{7 b}$ was quantitatively reduced into piperazine $\mathbf{8 b}$ (entry 2) and acridine 7c was hydrogenated selectively into 9,10-dihydroacridine in $98 \%$ yield (entry 3). Though catalyst (1PMF-ppt) did not allow any reduction of benzoquinoline 7d, catalyst (1PMF-imp) led to the hydrogenated product $\mathbf{8 d}$ in a $91 \%$ yield (entry 4).

Table 7. Hydrogenation of other $N$-heteroarenes 7a-f using catalysts (1PMF-ppt) and (1PMF-imp).
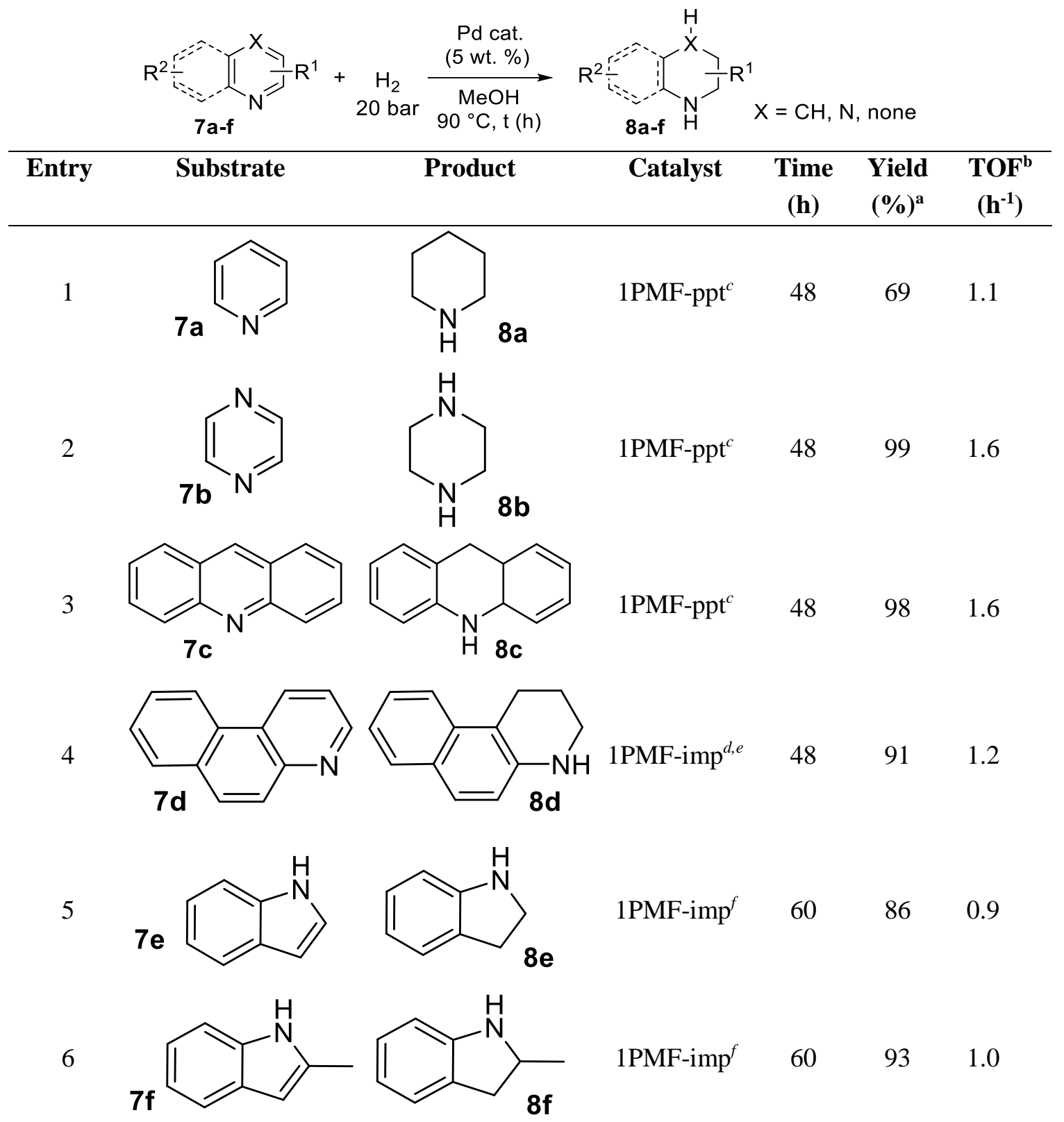

${ }^{a} \mathrm{GC}$ yields. ${ }^{b}$ Turnover frequency $=\mathrm{mol}$ of product $/ \mathrm{mol}$ of catalyst/hour. ${ }^{\mathrm{c}}$ Substrate $(0.055 \mathrm{mmol}, 0.1 \mathrm{~g}$ aver. $)$, catalyst (1PMF-ppt) (0.005 g, 5wt.\%, $0.013 \mathrm{~mol} \%$ of Pd), $\mathrm{MeOH}(5.0 \mathrm{~mL}), 20 \mathrm{bar} \mathrm{H}, 90{ }^{\circ} \mathrm{C} .{ }^{\mathrm{d}}$ Substrate $(0.055 \mathrm{mmol}, 0.1 \mathrm{~g}$ aver.), catalyst (1PMF-imp) (0.005 g, 5wt.\%, $0.016 \mathrm{~mol} \%$ of $\mathrm{Pd}), \mathrm{MeOH}(5.0 \mathrm{~mL}), 20 \mathrm{bar}_{2}, 90{ }^{\circ} \mathrm{C} .{ }^{e}$ No reaction with catalyst (1PMF-ppt). ${ }^{f}$ Substrate $(0.055 \mathrm{mmol}, 0.1 \mathrm{~g}$ aver.), catalyst (1PMF-imp) (0.005 g, 5wt.\%, $0.016 \mathrm{~mol} \%$ of Pd), (1R)-camphor

sulphonic acid (1 eq.), dichloroethane $(2.5 \mathrm{~mL}), 2,2,2$ fluroethanol $(2.5 \mathrm{~mL}), 20$ bar $\mathrm{H}_{2}, 90{ }^{\circ} \mathrm{C}$. No reaction without additional acid. 
Similarly, catalyst (1PMF-imp) was also necessary for the hydrogenation of indole 7e and 2methylindole 7f but, in spite the Brønsted and Lewis acidities of catalyst (1PMF-imp), the use of one equivalent of $(1 R)$-camphor sulphonic $\operatorname{acid}^{24}$ in a (1/1) dichloroethane and 2,2,2 fluroethanol solvent mixture was required in order to allow the reaction to proceed and recover hydrogenated products $8 \mathbf{e}$ and $\mathbf{8 f}$ in high yields (entries 5-6). On the whole, turnover frequencies were in the range of 0.9 to $1.6 \mathrm{~h}^{-1}$.

Overall, considering previous studies applying other palladium heterogeneous catalysts to the hydrogenation of $N$-heterocycles, ${ }^{13}$ the present catalysts operate at a lower palladium loading $(0.013 \mathrm{~mol} \%)$ then previously reported (from 5.0 to $0.1 \mathrm{~mol} \%)$. However, the reactions require higher temperatures, hydrogen pressures and reaction times to be effective, leading to rather modest turnover frequencies (TOF between 0.4 to $2.9 \mathrm{~h}^{-1}$ ).

The reusability of catalysts (1PMF-ppt) and (1PMF-imp) was studied for the hydrogenation of $N$-benzylideneaniline 1a into $N$-benzylaniline $\mathbf{2 a}$ under conditions affording reliable activity and stability features, over 11 runs and 10 recyclings (Figure 7). ${ }^{9}$ Thus, at the end of each run, the catalyst was separated from the reaction mixture by centrifugation, washed with methanol, dried at $80^{\circ} \mathrm{C}$ and used in the next catalytic assay. Regarding catalyst (1PMFppt), the first run provided $N$-benzylaniline $2 \mathrm{a}$ with $58 \%$ yield within 1 hour at $60^{\circ} \mathrm{C}$ (turnover frequency $21.5 \mathrm{~h}^{-1}$ ). The catalyst (1PMF-ppt) was then recycled ten times providing $\mathrm{N}$ benzylaniline $2 \mathbf{a}$ in $56 \%$ yield after the $10^{\text {th }}$ recycling (turnover frequency $20.7 \mathrm{~h}^{-1}$ ). By comparison, the first run with catalyst (1PMF-imp) led to $N$-benzylaniline $\mathbf{2 a}$ in a $40 \%$ yield within 0.5 hour at $60^{\circ} \mathrm{C}$ (turnover frequency $25.0 \mathrm{~h}^{-1}$ ). The catalyst (1PMF-imp) was subsequently recycled ten times leading to $N$-benzylaniline $2 \mathbf{a}$ in $38 \%$ yield after the $10^{\text {th }}$ recycling (turnover frequency $23.8 \mathrm{~h}^{-1}$ ). Therefore, both catalysts confirmed their good recycling ability without significant loss of activity and selectivity while keeping similar induction periods to reduce palladium particles from oxidation state (II) to (0) at the beginning of each run.
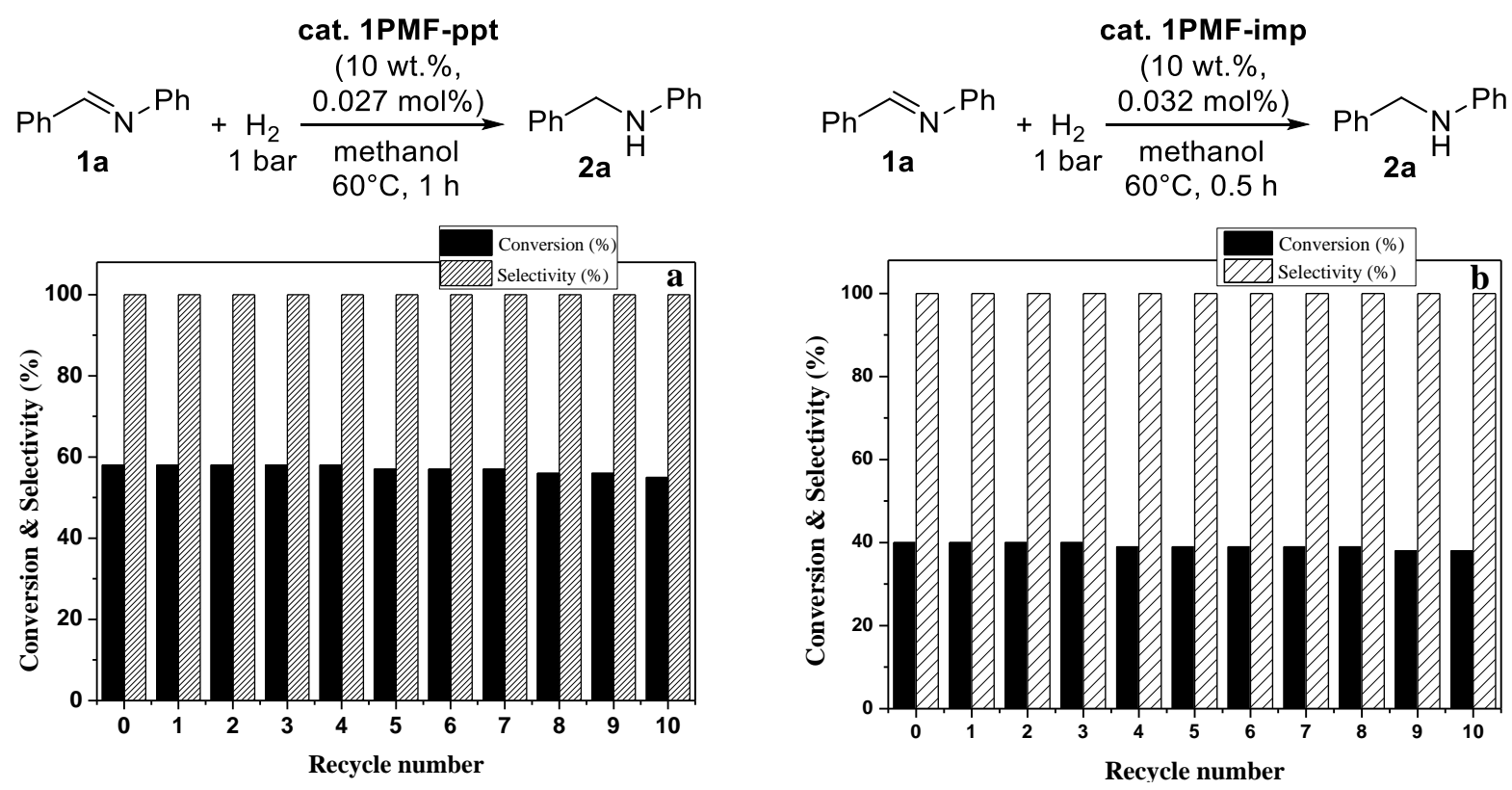

Figure 7. Reusability of (a) catalysts (1PMF-ppt) and (b) (1PMF-imp). 

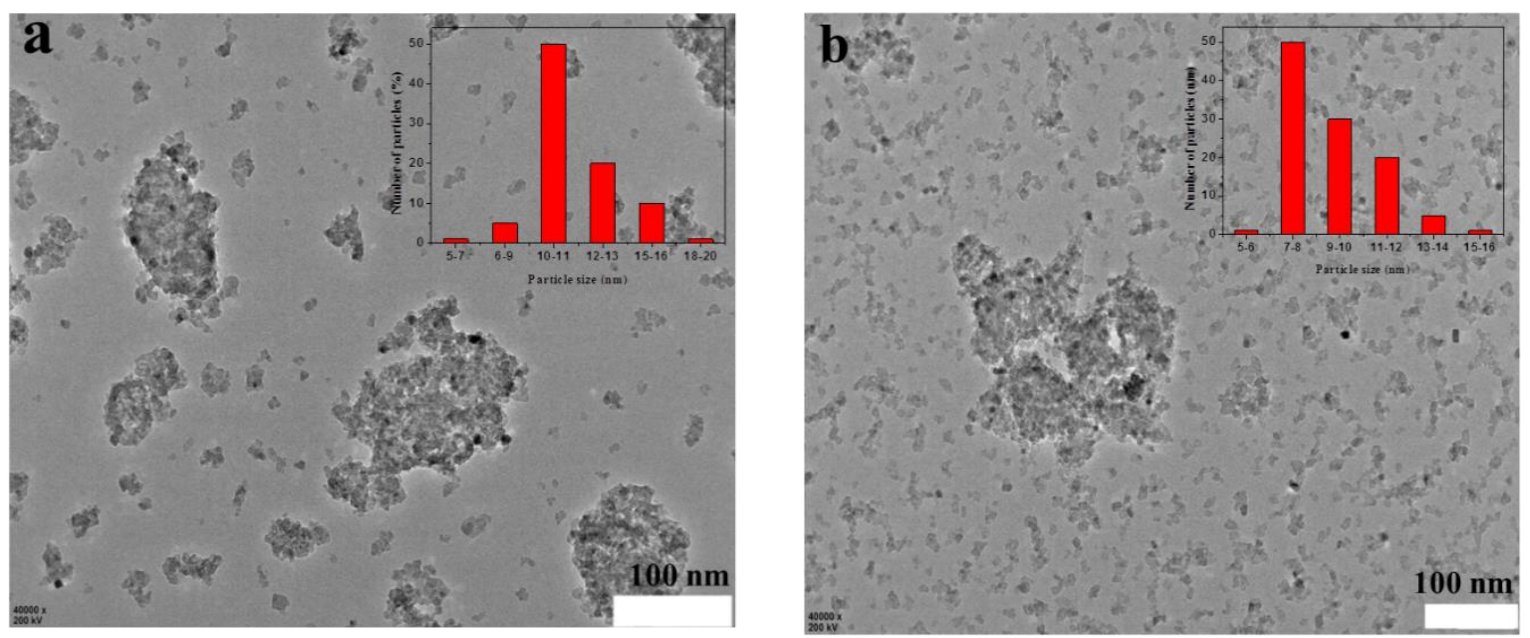

Figure 8. TEM analyses of used catalysts (a) (1PMF-ppt) and (b) (1PMF-imp).

Furthermore, in both cases, after a hydrogenation run, the supernatant obtained by a subsequent separation of the solid catalyst through centrifugation proved to be catalytic inactive without addition of further catalyst (see the S.I.). No palladium leaching was detected by ICP-AES analyses and, like with BET analyses (Figure S1, Table S1), TEM analyses of used catalysts PMF-ppt and PMF-imp revealed similar features to fresh catalysts (Figure 8). Indeed, for both type of catalysts, same average particle sizes were observed for fresh and used catalysts, particles being in a 10-11 nm range for used PMF-ppt catalyst and in a 7-8 nm range for used PMF-imp catalyst.

\section{Conclusion}

In summary, palladium catalysts supported on fluorinated magnesium hydroxide $\mathrm{Pd} / \mathrm{MgF}_{2-\mathrm{x}}(\mathrm{OH})_{\mathrm{x}}$ were prepared by precipitation or impregnation methods and showed excellent catalytic activities for the hydrogenation of various $\mathrm{C}=\mathrm{N}$ functionalities under rather mild reaction conditions. Aldimines and ketimines were readily reduced to the corresponding amines at 27 or $60{ }^{\circ} \mathrm{C}$ under one atmosphere of hydrogen. By using stronger temperature and hydrogen pressure $\left(90^{\circ} \mathrm{C}\right.$ and $\left.20 \mathrm{bar}\right)$, quinolines, pyridines and other $N$-heterocycles were successfully hydrogenated without the use of any acid additive. Such reactivity trend confirmed the positive effect of the acidic fluorinated magnesium hydroxide support on the $N$-heterocycle substrate pre-activation and therefore on the catalytic activity of the palladium nanoparticles during the hydrogenations. It was worth to note the catalyst prepared through impregnation method was the most active for the hydrogenation of several imines and $\mathrm{N}$-heterocycles probably due to its higher metal dispersion and smaller palladium particles by comparison to the catalyst prepared by precipitation method. To the best of our knowledge, according to previous studies on palladium heterogeneous catalysts applied to the hydrogenation of $\mathrm{N}$ heterocycles, ${ }^{13}$ the present catalysts operate at lower palladium loadings $(0.013$ or $0.016 \mathrm{~mol} \%)$ then previously reported (from 5.0 to $0.1 \mathrm{~mol} \%$ ). However, the reactions require higher temperatures, hydrogen pressures and reaction times to be effective, leading to rather modest turnover frequencies. Finally, by comparison to palladium on carbon, ${ }^{13 \mathrm{~b}}$ the catalysts remain 
reusable at the end of the hydrogenations and are recycled up to ten times without significant loss of activity and no palladium leaching is observed under the applied catalytic conditions.

\section{Experimental Section}

\section{Synthesis of catalyst (1PMF-ppt) by coprecipitation method ${ }^{18}$}

Under a well ventilated fume hood, a slurry of magnesium oxide $(3.193 \mathrm{~g})$ in $50 \mathrm{~mL}$ methanol and $10 \mathrm{~mL}$ distilled water was prepared in a $250 \mathrm{~mL}$ polypropylene beaker. Under stirring, a sub-stoichiometric amount of hydrofluoric acid (1.2 equivalents, $7 \mathrm{~mL} 40 \%$ aq.) was added dropwise. After dissolution of $\mathrm{MgO}$ in aqueous $\mathrm{HF}$, palladium acetate (1 wt \%) dissolved in methanol $(10 \mathrm{~mL})$ was then added under stirring over a period of $45 \mathrm{~min}$. The reaction mixture was subsequently stirred for an additional $3 \mathrm{~h}$ and further heated in a water bath at $80{ }^{\circ} \mathrm{C}$ until complete evaporation of solvent and formation of a powder. Finally, the prepared catalyst (1PMF-ppt) was heated at $250{ }^{\circ} \mathrm{C}$ in air for $5 \mathrm{~h}$.

\section{Synthesis of catalyst (1PMF-imp) by impregnation method}

Under a well ventilated fume hood, a slurry of magnesium oxide $(3.193 \mathrm{~g})$ in $50 \mathrm{~mL}$ methanol and $10 \mathrm{~mL}$ distilled water was prepared in a $250 \mathrm{~mL}$ polypropylene beaker. Under stirring, a sub-stoichiometric amount of hydrofluoric acid (1.2 equivalents, $7 \mathrm{~mL} 40 \%$ aq.) was added dropwise. After dissolution of $\mathrm{MgO}$ in aqueous $\mathrm{HF}$, the slow precipitation of $\mathrm{MgF}_{2-\mathrm{x}}(\mathrm{OH})_{\mathrm{x}}$ took place and the reaction mixture was stirred for an additional $1 \mathrm{~h}$. Afterwards, the resulting slurry was further heated in a water bath at $80{ }^{\circ} \mathrm{C}$ until complete evaporation of solvent and formation of a powder of $\mathrm{MgF}_{2-\mathrm{x}}(\mathrm{OH})_{\mathrm{x}}$ which was dried in an oven at $100{ }^{\circ} \mathrm{C}$. The resulting support was then dispersed in methanol and a solution of palladium acetate $(1 \mathrm{wt} \%)$ in methanol $(10 \mathrm{~mL})$ was added dropwise to the support slurry. The solution was stirred for $1 \mathrm{~h}$, and then the excess solvent was removed by heating the solution at $80{ }^{\circ} \mathrm{C}$ in a water bath until formation of a powder. The prepared catalyst (1PMF-imp) was then dried in an oven at $100{ }^{\circ} \mathrm{C}$ for $1 \mathrm{~h}$ and subsequently heated at $250{ }^{\circ} \mathrm{C}$ in air for $5 \mathrm{~h}$.

\section{General procedure for catalytic hydrogenations of imines}

Imine reagents $(0.055 \mathrm{mmol}$, around $0.1 \mathrm{~g}$ depending the substrate) and catalyst (1PMF-ppt) (0.005 g, 5wt.\%, $0.013 \mathrm{~mol} \%$ of Pd) or catalyst (1PMF-imp) (0.005 g, 5wt.\%, $0.016 \mathrm{~mol} \%$ of $\mathrm{Pd})$ were introduced in a Schlenk tube. After a vacuum purge, methanol $(5 \mathrm{~mL})$ was added under nitrogen and the flask connected to a balloon filled with hydrogen. After 3 vacuumhydrogen purges, the reaction mixture was heated at the given temperature under stirring for specific time. In order to follow the progress of the reaction, aliquots $(0.1 \mathrm{~mL})$ were taken at defined times, filtered through a pad of Celite, and washed with $\mathrm{CH}_{2} \mathrm{Cl}_{2}(3 \mathrm{~mL})$. The combined solvents were evaporated under reduced pressure and products were analysed by ${ }^{1} \mathrm{H}$ NMR. At the end of the reaction, solvent was evaporated under vacuum and the crude product was directly purified by flash chromatography or by preparative TLC.

\section{General procedure for catalytic hydrogenations of $\boldsymbol{N}$-heterocycles}

A $50 \mathrm{~mL}$ stainless-steel autoclave equipped with a magnetic stir bar was charged with the $\mathrm{N}$ heterocycle reagent $(0.055 \mathrm{mmol}$, around $0.1 \mathrm{~g}$ depending the substrate), catalyst (1PMF-ppt) 
(0.005 g, 5wt.\%, $0.013 \mathrm{~mol} \%$ of Pd) or catalyst (1PMF-imp) (0.005 g, 5wt.\%, $0.016 \mathrm{~mol} \%$ of $\mathrm{Pd})$ and methanol $(5 \mathrm{~mL})$. The autoclave was then filled with hydrogen at a pressure of $20 \mathrm{bar}$ after 3 purges. The reaction mixture was heated at $90{ }^{\circ} \mathrm{C}$ under stirring for defined time. At the end of the reaction, after cooling and depressurization, the solvent was evaporated under vacuum and the crude product was directly isolated by flash chromatography or preparative TLC.

\section{Procedure for catalyst recycling}

The catalyst recycling study was carried out by using imine 1a and catalyst (1PMF-ppt) or catalyst (1PMF-imp) under optimized reaction conditions: $0.5 \mathrm{~g}$ imine $1 \mathrm{a}, 0.05 \mathrm{~g}$ catalyst (1PMF-ppt) (10 wt \% catalyst with respect to substrate, $0.027 \mathrm{~mol} \%$ of $\mathrm{Pd}$ ) or $0.05 \mathrm{~g}$ catalyst (1PMF-imp) (10 wt \% catalyst with respect to substrate, $0.032 \mathrm{~mol} \%$ of Pd), $15.0 \mathrm{~mL}$ methanol solvent, balloon $\mathrm{H}_{2}, 27^{\circ} \mathrm{C}, 2 \mathrm{~h}$. At the end of the reaction, the catalyst was separated from the reaction mixture by centrifugation and the separated catalyst was washed with methanol for 23 times. Afterwards, the resulting solid was dried in an oven at $80^{\circ} \mathrm{C}$ and subsequently used as catalyst for the next reaction under identical experimental conditions. The same procedure was repeated for the next three recycle assays.

\section{See the Supporting Informations on the web for more experimental details (free of charge).}

\section{Acknowledgments}

This collaborative work was carried out under CNRS International Associated Laboratory program " Functionalized MATerials for SUstainable CATalytic and Related Applications MATSUCAT" between CSIR (NCL, Pune) India and CNRS (UCCS, Lille) France. RSK acknowledges CSIR for fellowship. The CSIR, the CNRS, the Chevreul Institute (FR 2638), the Ministère de l'Enseignement Supérieur et de la Recherche, the Région Nord - Pas de Calais and the FEDER are acknowledged for supporting and funding partially this work. Mrs Celine Delabre (UCCS) is thanked for her help with GC and GC-MS analyses.

\section{Author contribution}

Dr. Reshma Kokane: catalyst preparation, substrate synthesis, data collection, analysis and writing-editing. Dr. Yann Corre: substrate synthesis, data collection, analysis. Pr. Erhard Kemnitz, Dr. Mohan K. Dongare and Dr. Francine Agbossou-Niedercorn: catalyst design and designing of research. Dr. Christophe Michon: designing of research, data collection, analysis and writing-editing. Dr. Shubhangi B. Umbarkar: catalyst design, designing of research and writing-editing.

\section{Conflicts of interest}

There are no conflict to declare. 


\section{References}

1) a) P. Rylander, in The Catalytic Hydrogenation in Organic Syntheses; Academic Press: London, 1979; pp 213-234; b) S. Nishimura, in Handbook of Heterogeneous Catalytic Hydrogenations for Organic Synthesis; Wiley: New York, 2001; pp 497-571; c) J. G. De Vries, C. J. Elsevier, Handbook of Homogeneous Hydrogenation, Wiley-VCH, Weinheim, Germany, 2007; d) P. G. Andersson, I. J. Munslo, Modern Reduction Methods, 2008 Wiley-VCH, Weinheim; e) R. Noyori and T. Ohkuma, Angew. Chem. Int. Ed., 2001, 40, 40-73; f) N. B. Johnson, I. C. Lennon, I. C.; P. H. Moran and J. A. Ramsden, Acc. Chem. Res., 2007, 40, 1291-1299; g) W. S., Knowles and R. Noyori, Acc. Chem. Res., 2007, 40, 238-1239.

2) a) H. U. Blaser, C. Malan, B. Pugin, F. Spindler, H. Steiner and M. Studer, Adv. Synth. Catal., 2003, 345, 303-151; b) L. A. Saudan, Acc. Chem. Res., 2007, 40, 1309-1319; c) P. A. Dub and T. Ikariya, ACS Catal., 2012, 2, 1718-1741; d) S. Werkmeister, K. Junge and M. Beller, Org. Process Res. Dev., 2014, 18, 289-302; e) D. B. Bagal and B.M. Bhanage, Adv. Synth. Catal., 2015, 357, 883-900; f) M. Orlandi, D. Brenna, R. Harms, S. Jost and M. Benaglia, Org. Process Res. Dev., 2018, 22, 430-445; g) D. Formenti, F. Ferretti, F. K. Scharnagl and M. Beller, Chem. Rev., 2019, 119, 2611-2680.

3) a) R. H. Crabtree, Chem. Rev., 2012, 112, 1536-1554, b) D. S. Wang, Q. A. Chen, S. M. Lu and Y. G. Zhou, Chem. Rev., 2012, 112, 2557-2590; c) P. J. Deuss, K. Barta and J. G. de Vries, Catal. Sci. Technol., 2014, 4, 1174-1196.

4) a) D. Macquarrie, Fine Chemicals Synthesis Through Heterogenized Catalysts: Scopes, Challenges and Needs in Heterogenized Homogeneous Catalysts for Fine Chemicals Production: Materials and Processes (Eds.: P. Barbaro, F. Liguori), Springer Netherlands, Dordrecht, 2010, 1-35; b) M. J. Climent, A. Corma and S. Iborra, Chem. Rev., 2011, 111, 1072-1133; c) F. Meemken and A. Baiker, Chem. Rev., 2017, 117, 11522-11569; d) L. Zhang, M. Zhou, A. Wang and T. Zhang, Chem. Rev., 2020, 120, 683-733.

5) a) B. Balakrishna, J. L. Núñez-Rico and A. Vidal-Ferran, Eur. J. Org. Chem., 2015, 2015, 5293-5303; b) Z.-P. Chen and Y.-G. Zhou, Synthesis, 2016, 48, 1769-1781; c) G. A. Filonenko, R. van Putten, E. J. M. Hensen and E. A. Pidko, Chem. Soc. Rev., 2018, 47, 14591483; d) M.P. Wiesenfeldt, Z. Nairoukh, T. Dalton and F. Glorius, Angew. Chem. Int. Ed., 2019, 58, 10460-10476.

6) a) A. Fabrello, A. Bachelier, M. Urrutigoïty and P. Kalck, Coord. Chem. Rev., 2010, 254, 273-287; b) B. Li, J. Chen, Z. Zhang, I. D. Gridnev and W. Zhang, Angew. Chem. Int. Ed., 2019, 58, 7329-7334; c) U. Gupta, R. Krishnapriya and R.K. Sharma, ChemPlusChem, 2021, 86, 540-548; d) R. A. A. Abdine, G. Hedouin, F. Colobert and J. Wencel-Delord. ACS Catal., $2021,11,215-247$.

7) a) S.A. Lawrence, Amines: Synthesis, Properties and Applications, Cambridge University Press, Cambridge, UK, 2004; b) A. Ricci, Amino Group Chemistry: From Synthesis to the Life Sciences, Wiley VCH, Weinheim, 2008; c) S. D. Roughley and A. M. Jordan, J. Med. Chem., 2011, 54, 3451-3479; d) V. Sridharan, P. A. Suryavanshi and J. C. Menéndez, Chem. Rev., 2011, 111, 7157-7259; e) R. D. Taylor, M. MacCoss and A. D. G. Lawson, J. Med. Chem., 2014, 57, 5845-5859; f) E. Vitaku, D. T. Smith and J. T. Njardarson, J. Med. Chem., 2014, 57, 10257-10274; g) Top 200 pharmaceutical products by retail sales in 2018: 
https://njardarson.lab.arizona.edu/sites/njardarson.lab.arizona.edu/files/2018Top200Pharmace uticalRetailSalesPosterLowResFinalV2.pdf.

8) a) J. D. Keay in Comprehensive Organic Synthesis, Vol. 8 (Eds.: B. M. Trost, I. Fleming), Pergamon, Oxford, 1991, 579-601; b) V. Sridharan, P. Suryavanshi and J. C. Menendez, Chem. Rev., 2011, 111, 7157-7259.

9) a) J. A. Gladysz, Pure Appl. Chem., 2001, 73, 1319-1324; b) S. Hübner, J. G. de Vries and V. Farina, Adv. Synth. Catal., 2016, 358, 3-25; c) Á. Molnár and A. Papp, Coord. Chem. Rev., 2017, 349, 1-65.

10) a) G.-Y. Fan and J. Wu, Catal. Commun., 2013, 31, 81-85; b) A. Sanchez, M. Fang, A. Ahmed and R. A. Sanchez- Delgado, Appl. Catal. A, 2014, 477, 117-124; c) H. Y. Jiang and X. X. Zheng, Appl. Catal. A, 2015, 499, 118-123; d) M. Niu, Y. Wang, P. Chen, D. Du, J. Jiang and Z. Jin, Catal. Sci. Technol., 2015, 5, 4746-4749; e) F. Martinez-Espinar, P. Blondeau, P. Nolis, B. Chaudret, C. Claver, S. Castillón and C. Godard, J. Catal., 2017, 354, 113-127; f) M. N. Shaikh, Md. A. Aziz, A. N. Kalanthoden, A. Helal, A. S. Hakeem and M. Bououdinac, Catal. Sci. Technol., 2018, 8, 4709-4717; g) A. Karakulina, A. Gopakumar, Z. Fei and P. J. Dyson, Catal. Sci. Technol., 2018, 8, 5091-5097; h) Z. Luo, Y. Min, D. Nechiyil, W. Bacsa, Y. Tison, H. Martinez, P. Lecante, I. C. Gerber, P. Serpa and M. R. Axet, Catal. Sci. Technol., 2019, 9, 6884-6898.

11) a) N. A. Dehm, X. Zhang and J. M. Buriak, Inorg. Chem., 2010, 49, 2706-2714; b) D. Ge, L. Hu, J. Wang, X. Li, F. Qi, J. Lu, X. Cao and H. Gu, ChemCatChem, 2013, 5, 2183-2186; c) L. Bai, X. Wang, Q. Chen, Y. Ye, H. Zheng, J. Guo, Y. Yin and C. Gao, Angew. Chem., Int. Ed., 2016, 55, 15656-15661; d) S. Zhang, Z. Xia, T. Ni, Z. Zhang, Y. Ma and Y. Qu, J. Catal., 2018, 359, 101-111; e) H. Miyamura, A. Suzuki, T. Yasukawa and S. Kobayashi, J. Am. Chem. Soc., 2018, 140, 11325-11334.

12) a) L. Zhang, X. Wang, Y. Xue, X. Zeng, H. Chen, R. Li and S. Wang, Catal. Sci. Technol., 2014, 4, 1939-1948; b) M. Fang and R. A. Sánchez-Delgado, J. Catalysis, 2014, 311, $357-$ 368; c) H. Y. Jiang and X. X. Zheng, Catal. Sci. Technol., 2015, 5, 3728-3734; d) M. Tang, J. Deng, M. Li, X. Li, H. Li, Z. Chen and Y. Wang, Green Chem., 2016, 18, 6082-6090; e) H. Konnerth and M. H. G. Prechtl, Green Chem., 2017, 19, 2762-2767; f) T.-N. Ye, J. Li, M. Kitano and H. Hosono, Green Chem., 2017, 19, 749-756; g) W. Qian, L. Lin, Y. Qiao, X. Zhao, Z. Xu, H. Gong, D. Li, M. Chen, R. Huang and Z. Hou, Appl. Catal. A, 2019, 585, 117183-117195.

13) a) H. Norifumi, T. Yusuke, H. Takayoshi, S. Shogo, M. Takato, M. Tomoo, J. Koichiro and K. Kiyotomi, Chem. Lett., 2010, 39, 832-834; b) H. Mao, C. Chen, X. Liao and B. Shi, J. Mol. Cat. A: Chem., 2011, 341, 51-56; c) R. Rahi, M. Fang, A. Ahmed and R. A. SánchezDelgado, Dalton Trans., 2012, 41, 14490-14497; d) Y. Gong, P. Zhang, X. Xu, Y. Li, H. Li and Y. Wang, J. Catal., 2013, 293, 272-280; e) M. Guo, C. Li and Q. Yang, Catal. Sci. Technol., 2017, 7, 2221-2227; f) H. Sharma, M. Bhardwaj, M. Kour and S. Paul, Mol. Catal., 2017, 435, 58-68; g) Y. Ren, Y. Wang, X. Li, Z. Zhang and Q. Chi, New J. Chem., 2018, 42, 16694-16702; h) C. Chaudhari, K. Sato, Y. Nishida, T. Yamamoto, T. Toriyama, S. Matsumura, Y. Ikeda, K. Terada, N. Abe, K. Kusuda, H. Kitagawa and K. Nagaoka, RSC Adv., 2020, 10, 44191-44195. 
14) a) F. Chen, A.-E. Surkus, L. He, M.-M. Pohl, J. Radnik, C. Topf, K. Junge and M. Beller, J. Am. Chem. Soc., 2015, 137, 11718-11724; b) Z. Wei, Y. Chen, J. Wang, D. Su, M. Tang, S. Mao and Y. Wang, ACS Catal., 2016, 6, 5816-5822; c) P. Ji, K. Manna, Z. Lin, A. Urban, F. X. Greene, G. Lan and W. Lin, J. Am. Chem. Soc., 2016, 138, 12234-12242; d) I. Sorribes, L. Liu, A. Doménech-Carbó and A. Corma, ACS Catal., 2018, 8, 4545-4557; e) K. Murugesan, T. Senthamarai, M. Sohail, A. S. Alshammari, M-M. Pohl, M. Beller and R. V. Jagadeesh, Chem. Sci., 2018, 9, 8553-8560; f) K. Murugesan, V. G. Chandrashekhar, C. Kreyenschulte, M. Beller and R. V. Jagadeesh, Angew. Chem. Int. Ed., 2020, 59, 17408-17412.

15) a) Y.-F. He, J.-T. Feng, Y.-Y. Du and D.-Q. Li, ACS Catal., 2012, 2, 1703-1710; b) P. P. Sarmah and D. K. Dutta, Green Chem., 2012, 14, 1086-1093; c) J. Shi, Chem. Rev., 2013, 113, 2139-2181.

16) a) H. U. Blaser, H. Hönig, M. Studer and C. Wedemeyer-Exl, J. Mol. Catal. A, 1999, 139, 253-257; b) B. Zacharie, N. Moreau and C. Dockendorff, J. Org. Chem., 2001, 66, 5264-5265; c) F. Glorius, N. Spielkamp, S. Holle, R. Goddard and C. W. Lehmann, Angew. Chem. Int. Ed., 2004, 43, 2850-2852; d) A. Lei, M. Chen, M. He and X. Zhang, Eur. J. Org. Chem., 2006, 2006, 4343-4347; e) L. Piras, E. Genesio, C. Ghiron and M. Taddei, Synlett, 2008, 2008, $1125-$ 1128; f) M. Irfan, E. Petricci, T. N. Glasnov, M. Taddei and C. O. Kappe, Eur. J. Org. Chem., 2009, 2009, 1327-1334; g) D. S. Deng, G. Q. Han, X. Zhu, X. Xu, Y. T. Gong and Y. Wang, Chin. Chem. Lett., 2015, 26, 277-281; h) A. Karakulina, A. Gopakumar, I. AkÅok, B. L. Roulier, T. La Grange, S. A. Katsyuba, S. Das and P. J. Dyson, Angew. Chem. Int. Ed., 2016, 55, 292-296; i) F. Chen, W. Li, B. Sahoo, C. Kreyenschulte, G. Agostini, H. Lund, K. Junge and M. Beller, Angew. Chem. Int. Ed., 2018, 57, 14488-14492; j) N. Tanaka and T. Usuki, Eur. J. Org. Chem., 2020, 2020, 5514-5522.

17) a) A. M. Maj, I. Suisse, C. Méliet and F. Agbossou-Niedercorn, Tetrahedron: Asymmetry, 2010, 21, 2010-2014; b) A. M. Maj, I. Suisse, C. Hardouin and F. Agbossou-Niedercorn, Tetrahedron, 2013, 69, 9322-9328; c) A. M. Maj, I. Suisse, N. Pinault, N. Robert and F. Agbossou-Niedercorn, ChemCatChem, 2014, 6, 2621-2625; d) A. M. Maj, S. Heyte, M. Araque, F. Dumeignil, S. Paul, I. Suisse and F. Agbossou-Niedercorn, Tetrahedron, 2016, 72, 1375-1380; e) Y. Corre, X. Trivelli, F. Capet, J.-P. Djukic, F. Agbossou-Niedercorn and C. Michon, ChemCatChem, 2017, 9, 2009-2017; f) V. Rysak, A. Descamps-Mandine, P. Simon, F. Blanchard, L. Burylo, M. Trentesaux, M. Vandewalle, V. Collière, F. Agbossou-Niedercorn and C. Michon, Catal. Sci. Technol., 2018, 8, 3504-3512; g) S. Hayouni, C. Michon, D. Morvan, V. Belliere-Baca and F. Agbossou-Niedercorn, J. Organomet. Chem., 2020, 929, 121572-121576; h) V. Rysak, R. Dixit, X. Trivelli, N. Merle, F. Agbossou-Niedercorn, K. Vanka and C. Michon, Catal. Sci. Tech., 2020, 10, 4586-4592.

18) a) V. R. Acham, A. V. Biradar, M. K. Dongare, E. Kemnitz and S. B. Umbarkar, ChemCatChem, 2014, 6, 3182-3191; b) R. S. Kokane, V. R. Acham, A. B. Kulal, E. Kemnitz, M. K. Dongare and S. B. Umbarkar, ChemistrySelect, 2017, 2, 10618-10627.

19) de Jong K. P. Synthesis of solid catalysts. New York: John Wiley \& Sons. 2009.

20) https://sites.google.com/site/miller00828/in/solvent-polarity-table

21) C. A. Thomas, R. J. Bonilla, Y. Huang and P. G. Jessop, Can. J. Chem., 2001, 79, 719724. 
22) Y. P. Sun, H. Y. Fu, D. L. Zhang, R. X. Li, H. Chen and X. J. Li, Catal. Commun., 2010, 12, 188-192.

23) J. S. Dickstein, J. M. Curto, O. Gutierrez, C. A. Mulrooney and M. C. Kozlowski, J. Org. Chem., 2013, 78, 4744-4761.

24) a) D. S. Wang, J. Tang, Y. G. Zhou, M. W. Chen, C. B. Yu, Y. Duan and G. F. Jiang, Chem. Sci., 2011, 2, 803-806; b) Y. Duan, L. Li, M. W. Chen, C. B. Yu, H. J. Fan and Y. G. Zhou, J. Am. Chem. Soc., 2014, 136, 7688-7700. 